ISSN (print): 1698-6180. ISSN (online): 1886-7995

www.ucm.es/info/estratig/journal.htm

Journal of Iberian Geology 38 (1) 2012: 271-284

http://dx.doi.org/10.5209/rev_JIGE.2012.v38.n1.39217

\title{
The Bajo Segura Fault Zone: Active blind thrusting in the Eastern Betic Cordillera (SE Spain)
}

\section{La Zona de Falla del Bajo Segura: cabalgamiento activo "ciego" en la Cordillera Bética oriental}

\author{
P. Alfaro*1, R. Bartolomé ${ }^{2}$, M.J. Borque ${ }^{3}$, A. Estévez ${ }^{1}$, J. García-Mayordomo ${ }^{4}$, \\ F.J. García-Tortosa ${ }^{5}$, A.J. Gil ${ }^{3}$, E. Gràcia ${ }^{2}$, C. Lo Iacono ${ }^{2}$, H. Perea ${ }^{2}$ \\ ${ }^{1}$ Departamento de Ciencias de la Tierra y del Medio Ambiente. Universidad de Alicante, \\ Apdo. 99, 03080 Alicante, Spain. \\ ${ }^{2}$ Unitat de Tecnologia Marina-CSIC, Centre Mediterrani d'Investigacions Marines i Ambientals, \\ Psg. Maritim de la Barceloneta, 37-49, 08003, Barcelona, Spain. \\ ${ }^{3}$ Departamento de Ingeniería Cartográfica, Geodésica y Fotogrametría, Universidad de Jaén, \\ Campus de las Lagunillas s/n, 23071 Jaén, Spain. \\ ${ }^{4}$ Instituto Geológico y Minero de España, Ríos Rosas, 23. 28003 Madrid, Spain. \\ ${ }_{5}^{5}$ Departamento de Geología, Universidad de Jaén, Campus de las Lagunillas, 23071, Jaén, Spain. \\ *corresponding author: pedro.alfaro@ua.es
}

Received: 18/12/2011 / Accepted: 27/02/2012

\begin{abstract}
The Bajo Segura Fault Zone, located at the NE end of the Eastern Betic Shear Zone, has been the site of some of the most intense seismic activity on the Iberian Peninsula in the historical and instrumental time periods. This structure is an active blind fault that does not show any surface rupture. It is characterised by a set of ENE-WSW trending blind thrust faults that offset the Triassic basement and cause active folding of the Upper Miocene-Quaternary sedimentary cover. The main active structures of this fault zone are two ENE-WSW striking reverse blind faults, the Torremendo and the Bajo Segura Faults, and several secondary NW-SE striking dextral faults (San Miguel de Salinas, Torrevieja and Guardamar Faults). These structures continue offshore to the east. From geological, geomorphological and geodetic data, we obtain fault slip rates between 0.2 and $0.4 \mathrm{~mm} / \mathrm{yr}$, whereas other authors have proposed higher values ranging between 0.75 and $1 \mathrm{~mm} / \mathrm{yr}$. The fault zone can generate earthquakes with maximum estimated magnitudes (Mw) from 6.6 to 7.1 and has approximate recurrence intervals between 4.500 and 21.500 years.
\end{abstract}

Keywords: Active blind thrust, Bajo Segura Fault, Eastern Betic Shear Zone, Slip rate, Palaeoseismology 


\section{Resumen}

La Zona de Falla del Bajo Segura, localizada en el extremo NE de la Zona de Cizalla de la Bética Oriental, es una de las estructuras tectónicas de la Península Ibérica con mayor actividad sísmica asociada durante el periodo histórico e instrumental. Es una zona de falla ciega, sin ruptura en superficie, caracterizada por varios pliegues que deforman las rocas sedimentarias de edad Mioceno Superior a Cuaternario. Su traza principal tiene varios segmentos aproximadamente paralelos entre sí de dirección ENE-WSW entre los que destacan la Falla del Bajo Segura y la Falla de Torremendo. Además, tiene asociadas varias fallas de transferencia dextrorsas de dirección NW-SE (San Miguel de Salinas, Torrevieja y Guardamar). Estas fallas ENE-WSW y NW-SE tienen su continuidad hacia el este, en el Mar Mediterráneo. Algunos marcadores geológicos y geomorfológicos junto con un perfil de nivelación de alta precisión, han permitido obtener tasas de desplazamiento que varían entre 0.2 y $0.4 \mathrm{~mm} /$ año, aunque otros autores han propuesto valores más altos de entre 0.75 y $1 \mathrm{~mm} /$ año. A partir de estas tasas de desplazamiento y de la cartografía de la zona de falla, se estima que la máxima magnitud $\mathrm{Mw}$ varía entre 6.6 y 7.1 con periodos de recurrencia aproximados entre 4.500 y 21.500 años.

Palabras clave: Falla inversa ciega, Falla del Bajo Segura, Cordillera Bética, Tasa de desplazamiento, Paleosismicidad

\section{Introduction}

The Bajo Segura Fault Zone (BSFZ) (Fig. 1) has been the site of some of the most intense seismic activity on the Iberian Peninsula during the historical and instrumental periods (approximately the last 500 years). Along with parts of the Granada province, it is considered to be the area of highest seismic hazard in Spain, according to the official Seismic Hazard Map of Spain (Comisión Permanente de Normas Sismorresistentes, 2002).

The study area is characterised by low-magnitude earthquakes, although occasional destructive earthquakes have also occurred (Fig. 2). According to Giner et al. (2003), the earliest event with an assigned intensity is the 1048 Orihuela earthquake (I=X). Bisbal Cervello (1984) described two other events, in 1482 and 1484, with intensities of VIII to IX, respectively. However, these three historical earthquakes require additional studies (Giner et al., 2003). Other historical earthquakes related to the BSFZ are the 1523 Guardamar del Segura earthquake (I=VIII), the 1746 Rojales earthquake (I=VII) and earthquakes with intensity VII that occurred in 1802, 1828, 1837, 1867 and 1909 in Torrevieja. The most destructive event in the area was the 1829 Torrevieja earthquake $\left(\mathrm{I}_{\mathrm{MSK}}=\mathrm{X}\right)$, which caused 389 deaths and significant damage in Torrevieja and small towns in the River Segura valley (Rodríguez de la Torre, 1984; Muñoz et al., 1984; Muñoz and Udías, 1991; Delgado and López-Casado, 1999). This earthquake had an estimated Ms magnitude between 6.3 (Delgado et al., 1993) and 6.9 (Muñoz and Udías, 1991).

The instrumental seismicity recorded in the area over the last 100 years is characterised by earthquakes with magnitudes between 2.0 and 3.0. Occasionally, earthquakes with magnitudes approximately 4.0 occur, such as the 1979 San Miguel de Salinas earthquake $(\mathrm{mb}=4.2)$ and the 2003 East Torrevieja offshore earthquake $(\mathrm{mb}=4.0)$. In addition, in 1919 a composed earthquake characterised by two events 14 minutes apart $(\mathrm{mb}=5.1$ and 5.2$)$ occurred in Jacarilla (Fig. 2).

Over the last two decades, several active tectonics and palaeoseismological studies have focused on this fault zone (e.g., Taboada et al., 1993; Somoza, 1993, Alfaro et al., 1999, 2001, 2002a, b; García Mayordomo and Martínez Díaz, 2006; Giménez et al., 2009). The objective of this study is to integrate several seismological, palaeoseismological, tectonic and geodetic studies of the BSFZ, offering a review of one of the most active faults in the Iberian Peninsula.

\section{Geodynamic setting}

The study area is located in a diffuse collision zone between the African and Eurasian plates, which converge at approximately 4 to $5 \mathrm{~mm} / \mathrm{yr}$ (Argus et al., 1989; DeMets et al., 1994). The BSFZ is one of the main active faults of the Eastern Betic Shear Zone (sensu Silva et al., 1993; Gràcia et al., 2006), a $450 \mathrm{~km}$ left-lateral tectonic corridor (Bousquet, 1979). The BSFZ is located at the northern terminal splay of this shear zone, in the Bajo Segura Basin (Montenat, 1977). This Upper MioceneQuaternary basin is bordered to the north by the Crevillente Fault and by the BSFZ to the south. From the Late Miocene to the present, this basin has been subjected to NNW-SSE to NW-SE horizontal compression (Montenat et al., 1990; Alfaro, 1995). The focal mechanisms of recent earthquakes in this area indicate a similar regional stress field (Coca and Buforn, 1994; Buforn et al., 1995; Ramírez et al., 1998). The BSFZ, running $\sim \mathrm{E}-\mathrm{W}$ and oriented perpendicular to the regional stress field, shows reverse kinematics.

\section{Geometry and kinematics}

Although most of the Eastern Betic Shear Zone is characterised by good geomorphic and geologic evidence of 


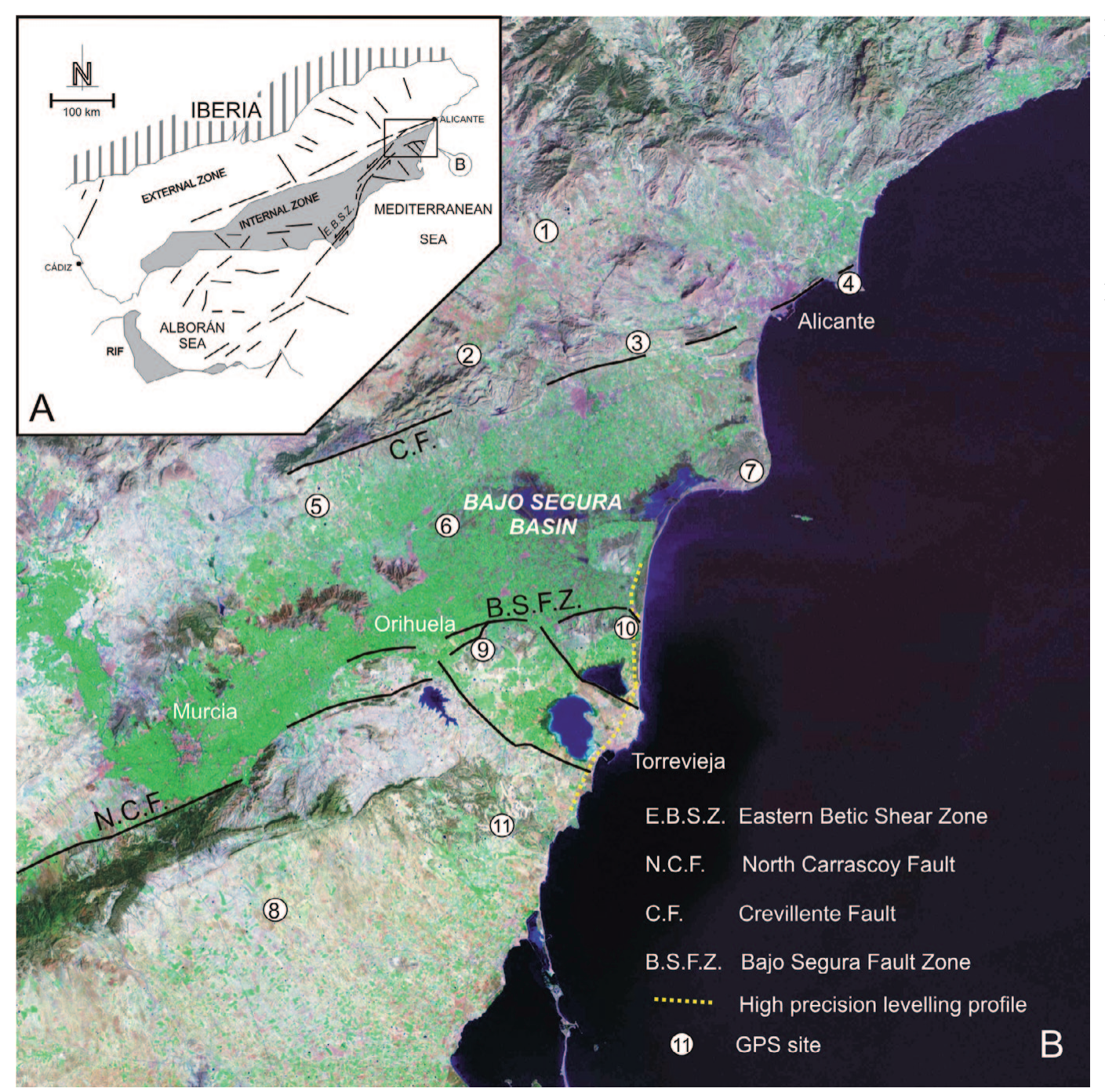

Fig. 1.- A. Map of the study area showing the location of the Eastern Betic Shear Zone (EBSZ). B. Map of the Bajo Segura Basin showing the location of the Bajo Segura Fault Zone (BSFZ), the high precision levelling profile and the GPS sites.

Fig. 1.- A. Mapa del área de estudio en el que se ha localizado la Zona de Cizalla de la Cordillera Bética Oriental (EBSZ). B. Mapa de la cuenca del Bajo Segura en el que se ha localizado la Zona de Falla del Bajo Segura (BSFZ). Además, se ha situado el perfil de nivelación de alta precisión y los puntos de control GPS del Bajo Segura.

left-lateral displacement (e.g., Alhama de Murcia Fault and Carboneras Fault; Silva, 1994; Masana et al., 2004), its northern terminal splay does not show any evidence of surface rupture. The BSFZ constitutes the eastern extension of the N60E trending North Carrascoy Fault, a reverse left-lateral active fault (Silva, 1994; Masana et al., 2004). The change in orientation of the Eastern Betic Shear Zone, from N60E (North Carrascoy Fault) to E-W (BSFZ), is also responsible for a change in fault kinematics.

The BSFZ is characterised by ENE-WSW trending blind thrusts that offset the Triassic basement and cause active folding of the Upper Miocene-Quaternary sedimentary cover (Fig. 3). The main active structures of this fault zone are two ENE-WSW trending reverse blind faults, the Torremendo and Bajo Segura Faults, and three secondary NW-SE dextral faults, the San Miguel de Salinas, Torrevieja and Guardamar faults. The recent activity of these faults has been responsible for the current topography of the basin, with uplifted areas correspond- ing to anticlines and subsiding areas related to growth synclines. Folding is not synchronous, as can be deduced from the analysis of progressive unconformities that have developed on the fold limbs.

\subsection{Surface deformation}

The main surface expression of the BSFZ is an ENEWSW trending anticlinorium that extends onshore from Zeneta to the Guardamar-Torrevieja coast (Fig. 3). The largest fold is the N70E trending Torremendo anticline, which is more than $25 \mathrm{~km}$ long and has progressive unconformities in Upper Miocene to Quaternary strata, as well as a set of smaller associated folds in both limbs. This anticline lies to the south of the San Miguel de Salinas Fault, which is subdivided into smaller secondary folds, the Punta Prima and Cabo Roig anticlines, separated by the gentle Cala del Bosque syncline. This anticlinorium is an asymmetric north verging fold, with a northern limb dipping $30^{\circ}$ towards the NE and a southern 


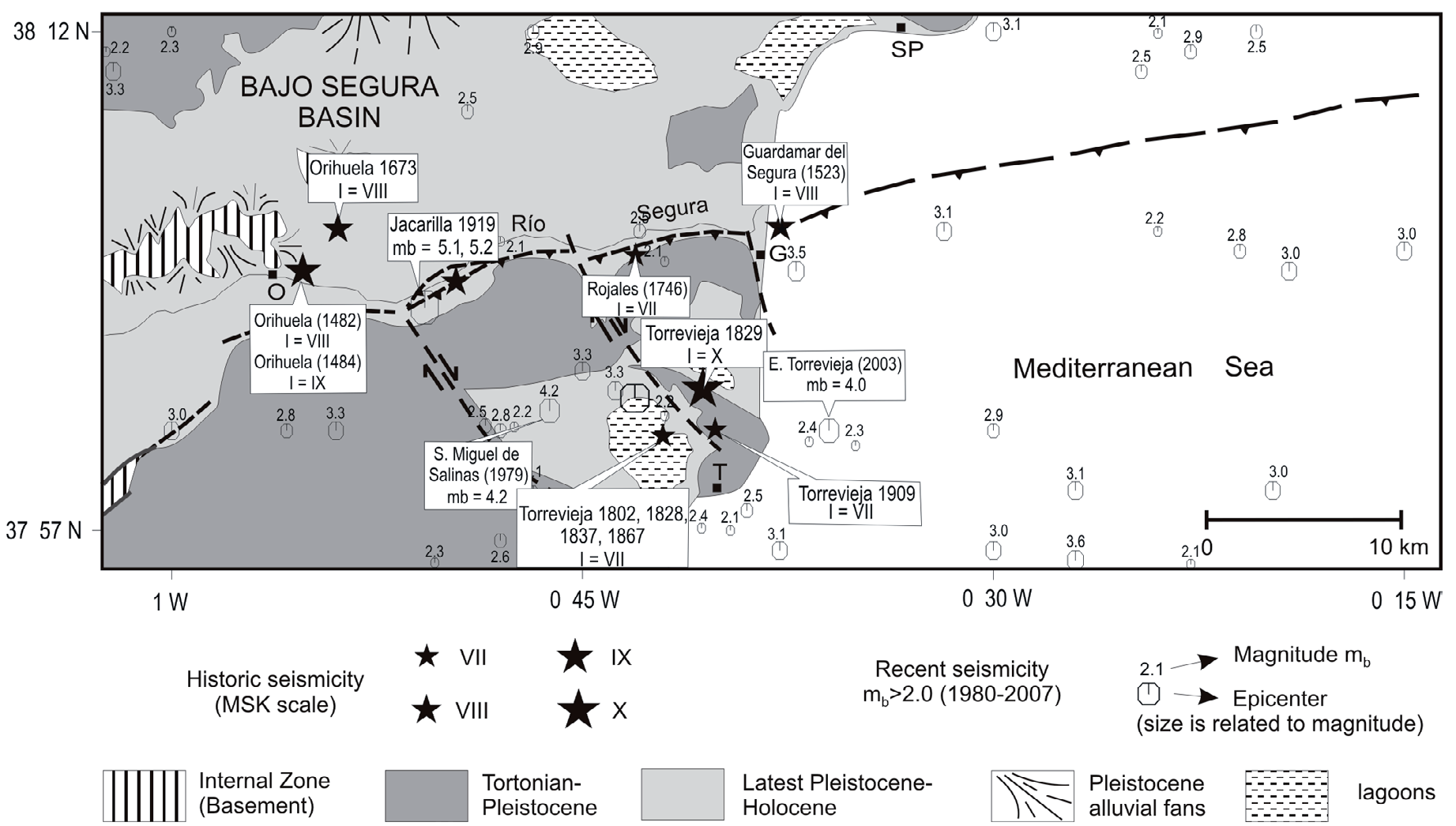

Fig. 2.- Historical and instrumental seismicity related to the BSFZ. Earthquakes are also located offshore along the eastern extension of the BSFZ.

Fig. 2.- Sismicidad histórica e instrumental asociada a la Zona de Falla del Bajo Segura. Los terremotos se prolongan hacia el Este, en el Mar Mediterráneo.

limb dipping less than $5^{\circ}$ southwards. To the south of this anticlinorium is the Campo de Cartagena, one of the most rapidly subsiding areas in the Betic Cordillera (Somoza, 1993; Sanz de Galdeano and Alfaro, 2004).

The Torremendo anticline is probably related to a detachment, the Torremendo Fault, at depth. This blind reverse fault extends from Zeneta to south of Jacarilla, where the San Miguel de Salinas Fault is located.

The Bajo Segura Fault is located to the north of the Torremendo Fault with an echelon geometry. This is also a blind reverse fault and extends onshore from south of Orihuela to Guardamar del Segura (Figs. 2 to 4). Its surface expression is characterised by several ENE-WSW trending active folds (Figs. 5 and 6); from east to west, these are the Guardamar, Lomas de La Juliana-Benejúzar and Hurchillo anticlines. These anticlines are north-verging, with steep forelimbs on the north and gentle back limbs on the south. Although they are generally gentle or open folds, the strata of the Pliocene-Pleistocene? Conglomerados del Segura Formation (Montenat, 1977) are vertical in the north limb of the Hurchillo anticline (Fig. 6). Synclines have developed on both sides of the anticlines, forming areas of subsidence. The Segura River flows parallel to the fold axes of the northern syncline, along the depocentre and very close to the northern forelimb. According to coseismic deformation models (e.g., Taboada et al., 1993), the Bajo Segura Fault dips steeply to the south (Alfaro et al., 2002a). The most modern folded beds visible at surface in these anticlines are of Pleistocene age. Alfaro et al. (2002a) also identified Pleistocene syntectonic strata in the northern growth syncline in high-resolution seismic profiles. Nevertheless, the most recent sedimentary unit, deposited during the Latest Pleistocene-Holocene (Soria et al., 1999) is horizontal and has not been appreciably deformed. This unit is $\sim 30$ $m$ thick and obscures the deformation in the central part of the basin along the present Segura River valley.

\subsection{Offshore extension of the BSFZ}

Based on an integrated analysis of commercial seismic reflection profiles, wells, gravity data, seismicity and surface geology of the Bajo Segura Basin and its eastern extension in the Alicante shelf, Alfaro et al. (2002b) observed that the Eastern Betic Shear Zone continues offshore to the east. They observed similar geologic characteristics in both the BSFZ and the offshore region, which is characterised by active folding and thrusting of the Up- 
per Miocene to Quaternary sedimentary cover.

In September 2008, the marine geophysical cruise Event-Shelf was carried out on-board the Spanish RV García del Cid. The main objective was to image the active structures located on the northern and southern marine terminations of the EBSZ, focusing on the shelf area (Perea et al., 2010; Perea et al., 2012). During the cruise, ten single-channel sparker seismic profiles were acquired along and across the BSFZ. Six units were identified in the seismic profiles, which show a regional erosive upper boundary in the shallow areas that becomes concordant with the lower units in the centre of the basin. All of these units have been identified as Quaternary in age, and the upper horizons have been identified as ancient palaeoshorelines that can be correlated with marine isotopic stages 12 (434 ka) to 2 (20 ka) (Perea et al., 2012).
The main geological structure in the offshore basin is the Tabarca anticline ridge (20-30 km wide), which extends approximately $80 \mathrm{~km}$ from the coast in an ENEWSW direction (Alfaro et al., 2002b; Perea et al., 2012). This structure has been uplifted by several faults and folds that can be grouped into the following deformation zones from north to south (Perea et al., 2012): a) the Santa Pola fault zone, characterised by E-W trending faults and folds, and a southern syncline that is correlated with the Salinas de Santa Pola syncline onshore; b) the La Marina fault zone, composed of WSW-ENE trending faults and folds that die out to the east, where they appear to join the structures of the Santa Pola fault zone; c) the Guardamar fault zone, which is one of the main E-W trending deformation zones and is an important uplift, highlighting the Bajo Segura thrust and the Guardamar anticline; d)

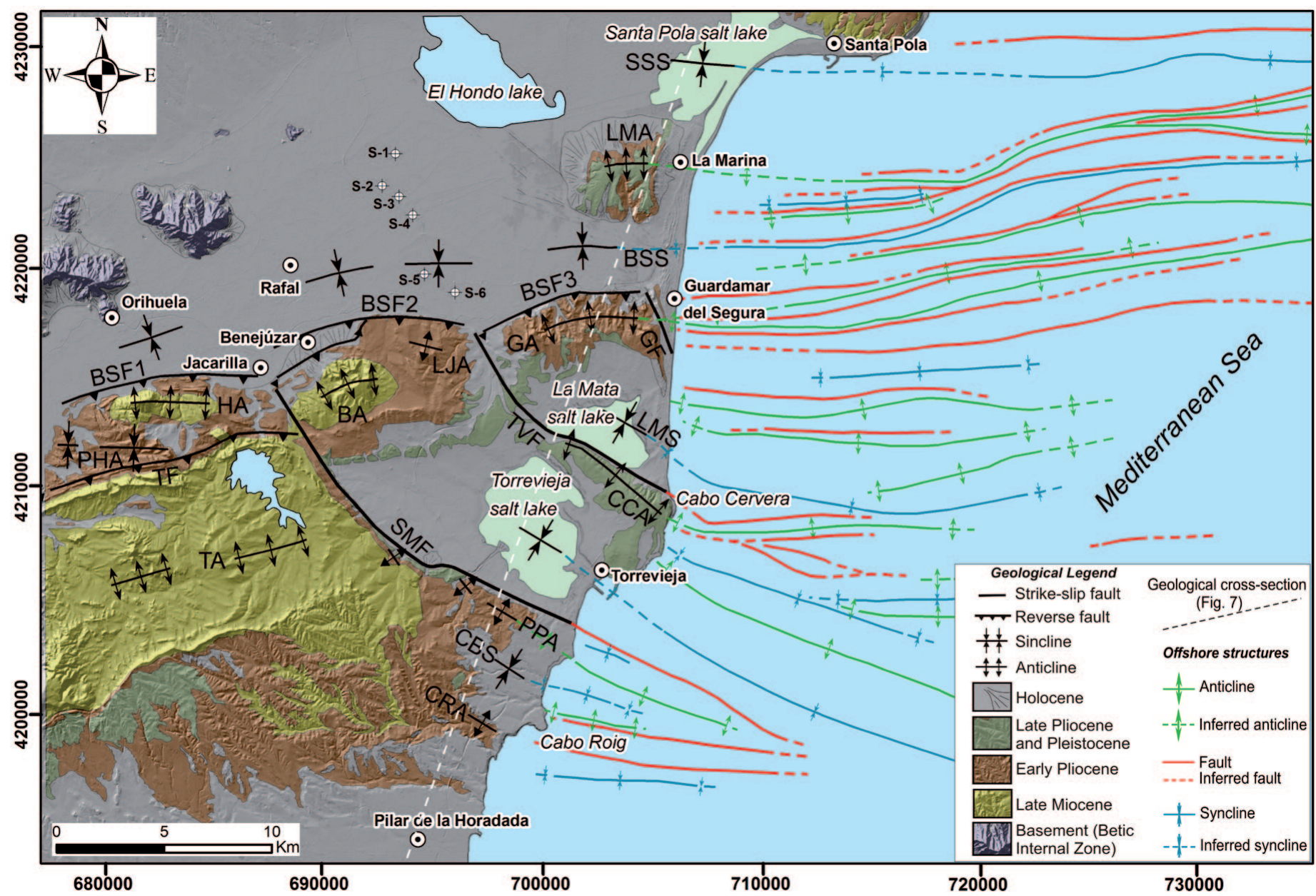

Fig. 3.- Geological map of the BSFZ. The six boreholes from Fig. 8A are shown. BSF: Bajo Segura Fault, TF: Torremendo Fault, SMF: San Miguel de Salinas Fault, TVF: Torrevieja Fault, GF: Guardamar Fault, SSS: Salinas de Santa Pola syncline, LMA: La Marina anticline, BSS: Bajo Segura syncline, GA: Guardamar anticline, LMS: La Mata syncline, CCA: Cabo Cervera anticline, TS: Torrevieja syncline, PPA: Punta Prima anticline, CBS: Cala del Bosque syncline, CRA: Cabo Roig anticline.

Fig. 3.- Mapa geológico de la Zona de Falla del Bajo Segura, en el que se han localizado los seis sondeos de la Fig. 8A. BSF: Falla del Bajo Segura, TF: Falla de Torremendo, SMF: Falla de San Miguel de Salinas, TVF: Falla de Torrevieja, GF: Falla de Guardamar, SSS: Sinclinal de las Salinas de Santa Pola, LMA: Anticlinal de La Marina, BSS: Sinclinal del Bajo Segura, GA: Anticlinal de Guardamar, LMS: Sinclinal de La Mata, CCA: Anticlinal de Cabo Cervera, TS: Sinclinal de Torrevieja, PPA: Anticlinal de Punta Prima, CBS: Sinclinal de la Cala del Bosque, CRA: Anticlinal de Cabo Roig. 
A SE
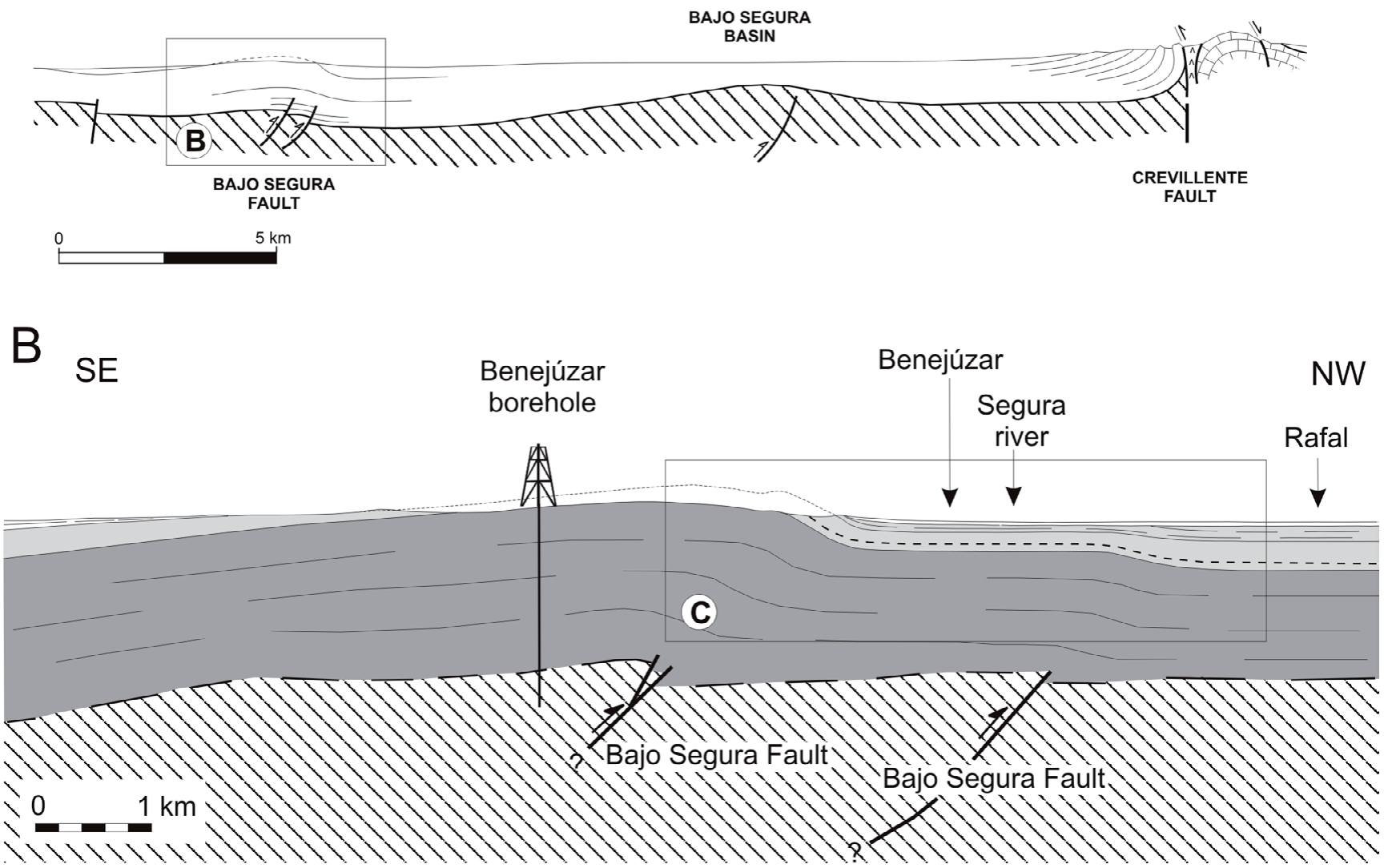

Basement Internal Zone

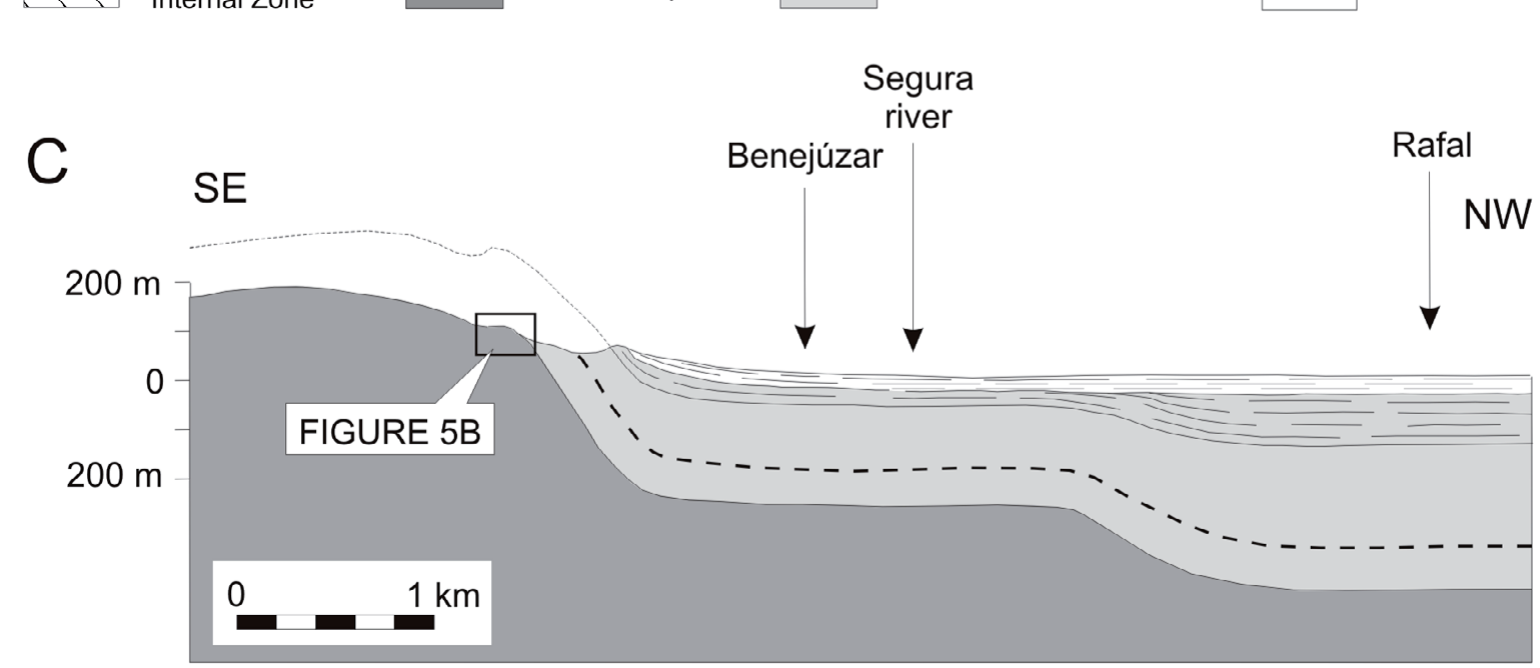

Miocene Sup.

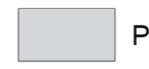

Pliocene-Pleistocene

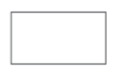

Latest Pleistocene-Holocene

$\ldots+\ldots$ Onset of folding

Fig. 4.- A) Simplified geological cross-section of the Bajo Segura Basin showing the location of the BSFZ. The location of Fig. 4B is indicated by the square. B) NW-SE geological cross-section of the Benejúzar anticline. The location of Fig. 4C is indicated by the square. C) Detail of the northern limb of the Benejúzar anticline from a high-resolution seismic profile (Alfaro et al., 2002a), where syntectonic strata related to the fault activity are shown. The location of Fig. 5B is indicated by the square.

Fig. 4.- A) Corte geológico esquemático de la Cuenca del Bajo Segura, con la localización de la Zona de Falla del Bajo Segura. Se ha indicado con un recuadro la localización de la Fig. 4B. B) Corte geológico del anticlinal de Benejúzar según la dirección NO-SE. El recuadro indica la localización de la Fig. 4C. C) Detalle del flanco septentrional del anticlinal de Benejúzar realizado a partir de un perfil sísmico de alta resolución (Alfaro et al., 2002a) en el que se muestra el relleno sintectónico asociado a la actividad de la falla. El recuadro indica la localización de la Fig. 5B. 

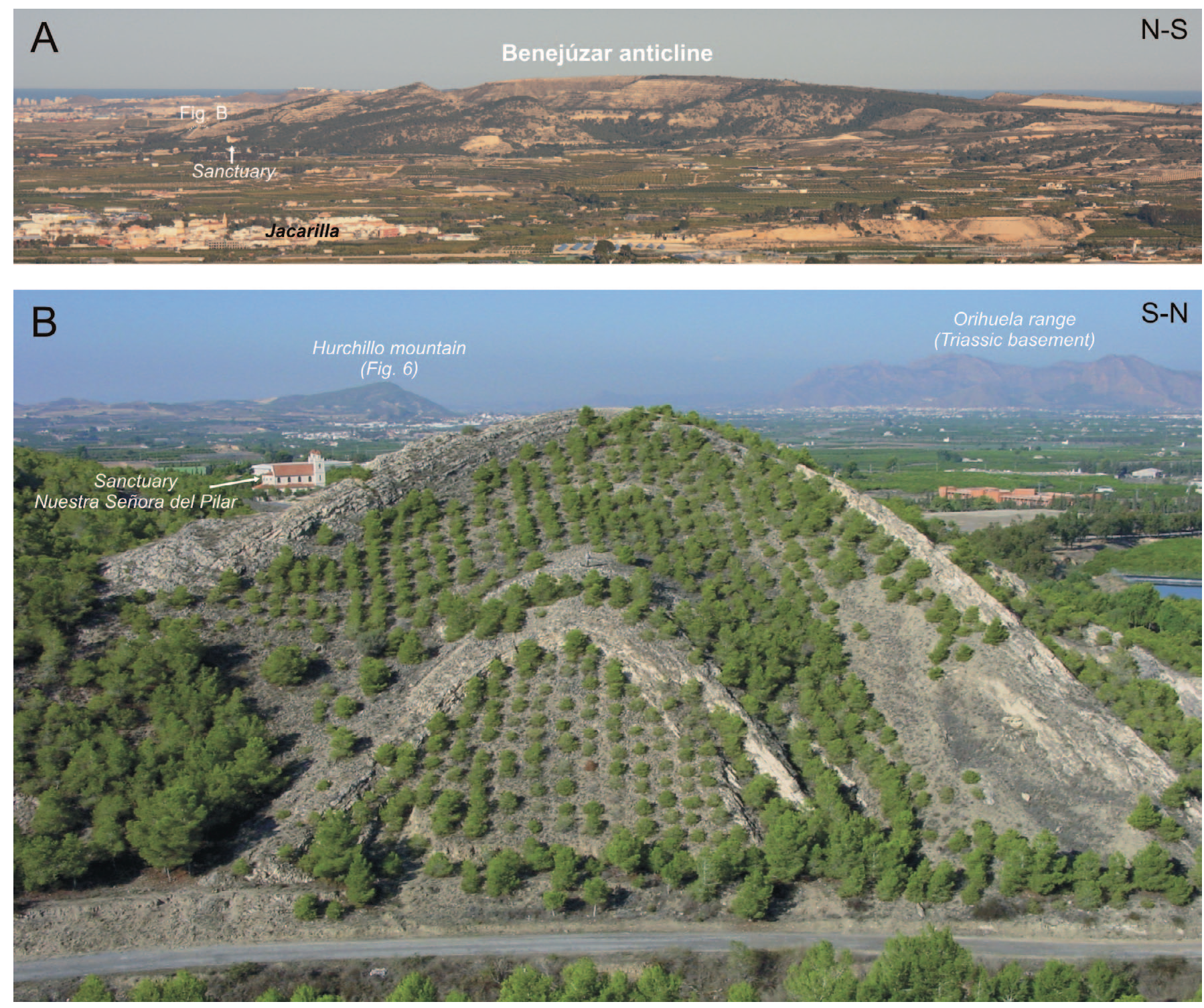

Fig. 5.- A) Panoramic view, from west to east, of the Benejúzar anticline. The location of Fig. 5B is also indicated. B) El Pilar anticline, a hectometric-scale fold located in the northern limb of the Benejúzar anticline.

Fig. 5.-. A) Vista panorámica de oeste a este del anticlinal de Benejúzar. Se ha señalado la localización de la Fig. 5B. B) Anticlinal del Pilar, un pliegue hectométrico localizado en el flanco septentrional del anticlinal de Benejúzar.

the Torrevieja fault zone, which has faults and folds that change strike from E-W to WSW-ENE and propagate 8 to $10 \mathrm{~km}$ offshore; the most important of these structures are the Torrevieja fault and the Cap de Cervera anticline; e) the Torrevieja fold zone, which is composed of a number of E-W and WNW-ESE-trending anticlines and synclines that propagate 15 to $20 \mathrm{~km}$ offshore, with the Torrevieja syncline being the most relevant structure; and f) the San Miguel de Salinas fault zone, which contains faults and folds that appear to extend 10 to $15 \mathrm{~km}$ offshore and are oriented WNW-ESE in the north and E-W in the south. The main structures correlate with the San Miguel de Salinas fault, the Punta Prima anticline and the Cala del Bosque syncline. In general, the faults and folds along the
Bajo Segura offshore basin deform the upper Quaternary units, in most cases affecting units with interpreted ages between $135 \mathrm{ka}$ and $20 \mathrm{ka}$ (Perea et al., 2012). Accordingly, most of these structures should be considered to be active, and on the basis of their dimensions, they are capable of producing large earthquakes.

\section{Palaeoseismic studies}

The Bajo Segura Fault Zone is a blind reverse fault and, therefore, traditional palaeoseismologic studies based on the analysis of natural outcrops or excavated trench exposures to identify fault rupture events, are not possible. Nevertheless, some liquefaction features were de- 
scribed during large historical earthquakes that occurred in the area. For example, the 1829 Torrevieja earthquake produced sand volcanoes and fissures over an area of 7 $\mathrm{km}^{2}$ (Larramendi, 1829), and during the 1919 Jacarilla earthquake $(\mathrm{mb}=5.2)$, liquefaction was observed near the village (Kindelán and Gorostízaga, 1920; Delgado et al., 1998, 2003).

The Bajo Segura Basin is filled by Quaternary alluvial and coastal sediments that are highly susceptible to liquefaction. Unfortunately, the water table is very shallow and only 1 to $2 \mathrm{~m}$ of sediments is exposed above the water table, most of which has been reworked by agricultural activity. Alfaro et al. (2001) conducted a study in which six boreholes $40 \mathrm{~m}$ deep were drilled in the Holocene and Upper Pleistocene sediments (Fig. 8). They identified 25 soft-sediment deformation structures that they interpreted to be the result of seismic liquefaction. Moreover, 30 radiometric ${ }^{14} \mathrm{C}$ dates were obtained, allowing the calculation of sedimentation rates (Soria et al., 1999) and the most probable age for each seismite (Alfaro et al., 2001). Alfaro et al. (2001) identified at least seven palaeoearthquakes over the last 8000 years in the Bajo Segura Basin (Fig. 8). From these palaeoearthquakes and the 1829 Torrevieja earthquake, they obtained a minimum recurrence interval for moderate earthquakes of approximately 1000 years (magnitude $>5.0$ ). Although the use of palaeoliquefaction features does not allow the seismogenic source of a palaeoearthquake to be identified, the Bajo Segura Fault Zone is the most likely causative fault.

\section{Discussion}

The deep tectonic structure of the BSFZ, which is characterised by blind thrusts, still remains an open issue. Some alternatives range from a single reverse fault or thrust duplex to a ramp-flat system (e.g., Taboada et al., 1993). We focus this study on the Bajo Segura Fault, assuming that a single blind fault is responsible for the Hurchillo, Benejúzar and Guardamar folds.

We estimated uplift rates produced by this active fault from geological, geomorphological and geodetic studies. The estimate of fault slip rates is based on previous work by Taboada et al. (1993) and on more precise chronological data of the deformation markers.

\subsection{Slip rates}

Taboada et al. (1993) proposed the first slip rates related to the Bajo Segura Fault using a coseismic deformation model. They used three assumptions to estimate fault movements at depth and the resulting slip rates. According to these authors, active folding started during the
Early Pleistocene (2 Ma or $1.5 \mathrm{Ma}$ ). The obtained slip rates ranged between 0.75 and $1 \mathrm{~mm} / \mathrm{yr}$, and the recurrence periods for two possible earthquake magnitudes $(\mathrm{Ms}=7$ and $\mathrm{Ms}=6.7)$ are 1000 to $2000 \mathrm{yr}$, respectively.

\subsubsection{Geologic and geomorphic markers}

Several geological and geomorphic markers of different ages have been used to calculate uplift rates related to the activity of the Bajo Segura Fault. Somoza (1993) estimated regional uplift rates based on different heights of Tyrrhenian marine terraces. They obtained regional uplift rates of $\pm 0.2 \mathrm{~mm} / \mathrm{yr}$, with the Bajo Segura Fault being one of the causative active structures of this uplift.

Alfaro et al. (2002a), using the Triassic basement (Alpujarride, Internal Zone) as a marker, interpreted $500 \mathrm{~m}$ of vertical displacement on the Bajo Segura Fault from seismic profiles and oil exploration wells. This amount of displacement has also been interpreted from gravimetric data (Gauyau, 1977). Assuming that active folding started $4 \mathrm{Ma}$ ago, the estimated uplift rate is $0.12 \mathrm{~mm} / \mathrm{yr}$.

García-Mayordomo and Martínez-Díaz (2006) estimated vertical slip rates of $0.30,0.20$ and $0.10 \mathrm{~mm} / \mathrm{yr}$ for the Hurchillo, Benejúzar and Guardamar folds, respectively, using the structure contour map of the Pliocene surface presented in Taboada et al. (1993). García-Mayordomo and Martínez-Díaz (2006) also estimated an average net slip rate of $0.23 \mathrm{~mm} / \mathrm{yr}$ for the Bajo Segura Fault.

Giménez et al. (2009) used the top of the Rojales Sandstones (Areniscas de Rojales Formation sensu Montenat, 1977) as a stratigraphic marker to determine long-term uplift rates related to the Bajo Segura Fault. In the Guardamar segment, this marker has undergone approximately $300 \mathrm{~m}$ of vertical displacement (Giménez et al., 2009). Assuming that this displacement was produced in the last 2 or $3 \mathrm{Ma}$, they obtained an uplift rate between 0.10 and $0.15 \mathrm{~mm} / \mathrm{yr}$.

\subsubsection{Geodetic studies}

To estimate the present-day deformation of the Bajo Segura Basin, a GPS network with 11 control points (Fig. 1) was installed and measured for the first time in 1999 (Alfaro et al., 2000). Sites 1 to 5 were designed to measure the deformation along the Crevillente Fault, whereas sites 6 to 11 were designed to measure the deformation along the BSFZ. Sites 6 and 7 are located to the north of the fault zone, sites 9 and 10 are located on the Benejúzar and Guardamar anticlines, and sites 8 and 11 are located to the south of the fault zone.

In addition, a $30 \mathrm{~km}$ long high-precision levelling profile was set up along the eastern Bajo Segura Basin to quantify the vertical uplift associated with the BSFZ (Fig. 7). This N-S to NNW-SSE levelling line crosses 

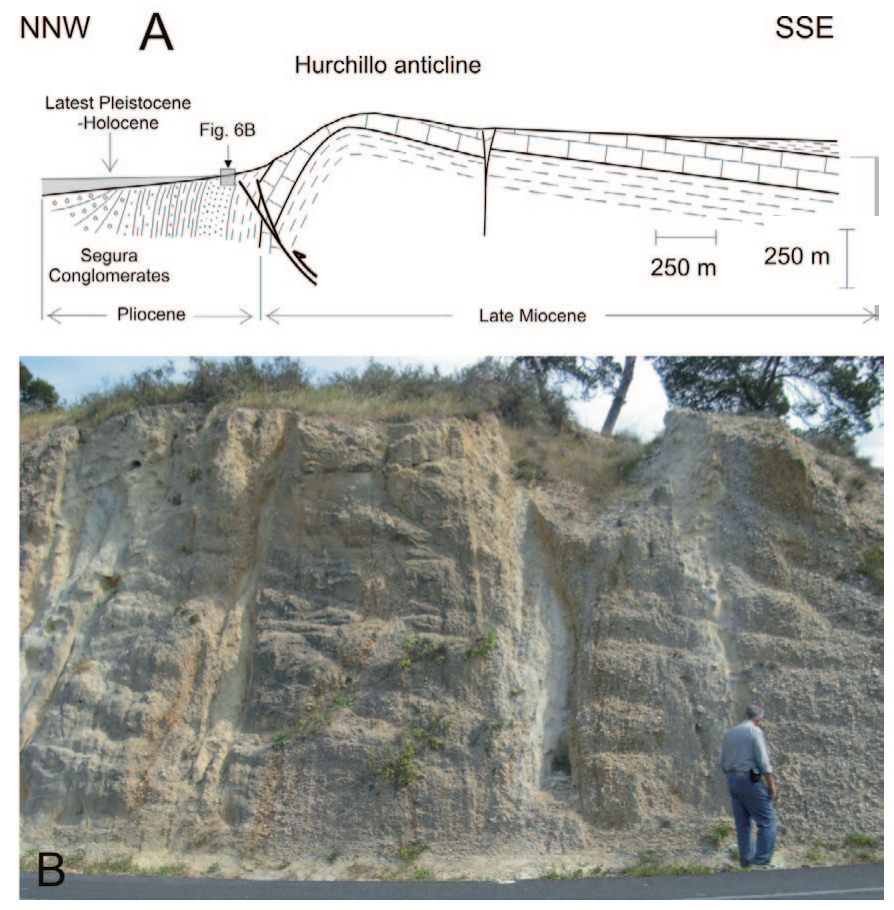

Fig 6.- A) Geological cross-section of the Hurchillo anticline. B) Detail of the Segura Conglomerate Formation, near the Hurchillo village, where Pliocene strata dip $90^{\circ}$.

Fig. 6.- A) Corte geológico del anticlinal de Hurchillo. B) Detalle de la Formación Conglomerados del Segura, en las proximidades de la población de Hurchillo, donde los estratos del Plioceno están verticales.

the main trace of the Bajo Segura, Torrevieja and San Miguel de Salinas faults and several active folds. A total of 44 benchmarks distributed between La Marina and Cabo Roig were measured during the 2003 levelling campaign (Giménez et al., 2009). The height differences from the 2003 campaign were compared with those from the 1976 (IGN, Instituto Geográfico Nacional) and 1997 campaigns (Giménez et al., 2000), resulting in two recent vertical movement profiles (1976-2003 and 1997-2003). Giménez et al. (2009) estimated small vertical movements of similar magnitude to the errors. They also observed two steps of $0.2 \mathrm{~mm} / \mathrm{yr}$ vertical velocity that can be correlated to different structures of the BSFZ, and a regional tilting of $0.4 \mathrm{~mm} / \mathrm{km}$ towards the south, which agrees with the regional tilting deduced using Tyrrhenian marine terraces (Somoza, 1993).

\subsection{Seismic hazard of the Bajo Segura Fault}

The seismogenic potential and recurrence of the maximum earthquakes on the Bajo Segura Fault were previously studied by García-Mayordomo (2005) and GarcíaMayordomo and Martínez-Díaz (2006). These authors based their estimates primarily on measurements from regional geological maps and slip rates derived using a marker formerly attributed to the Early Pleistocene. Nevertheless, new observations on the age of this marker, as well as the availability of more accurate maps of the fault trace, call for a revision of the seismogenic potential of the Bajo Segura Fault.

\subsubsection{Segmentation and maximum magnitudes}

The Bajo Segura Fault shows distinct variations in structure, deformation patterns and slip rates, which strongly suggest its segmentation. The Hurchillo, Benejúzar and Guardamar fold trends show a gradient in the tightness of the folds, with their northern limbs dipping

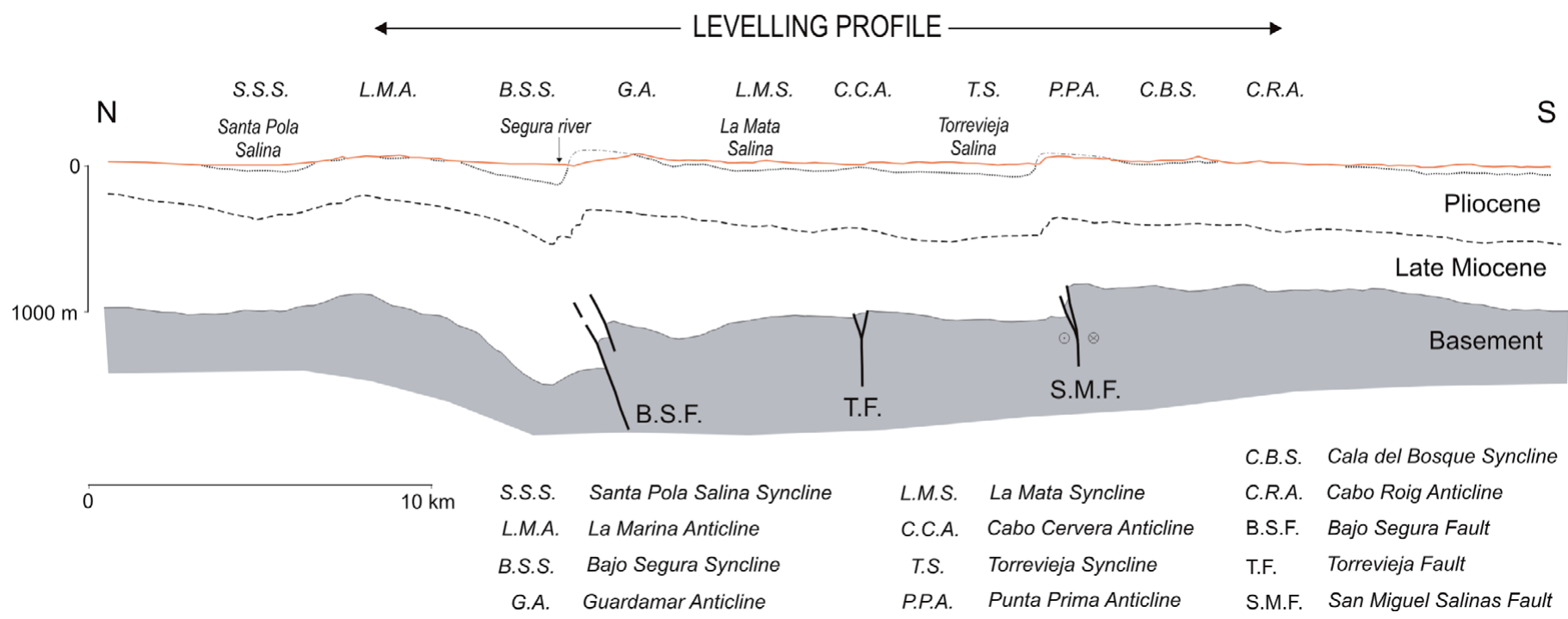

Fig. 7.-. Geological cross-section, oriented approximately parallel to the levelling profile, showing active folding. The location is shown in Fig. 3. Note the vertical scale exaggeration.

Fig. 7.- Corte geológico aproximadamente paralelo al perfil de nivelación de alta precisión en el que se muestran las principales estructuras activas. La situación del corte está indicada en la Fig. 3. La escala vertical está exagerada. 

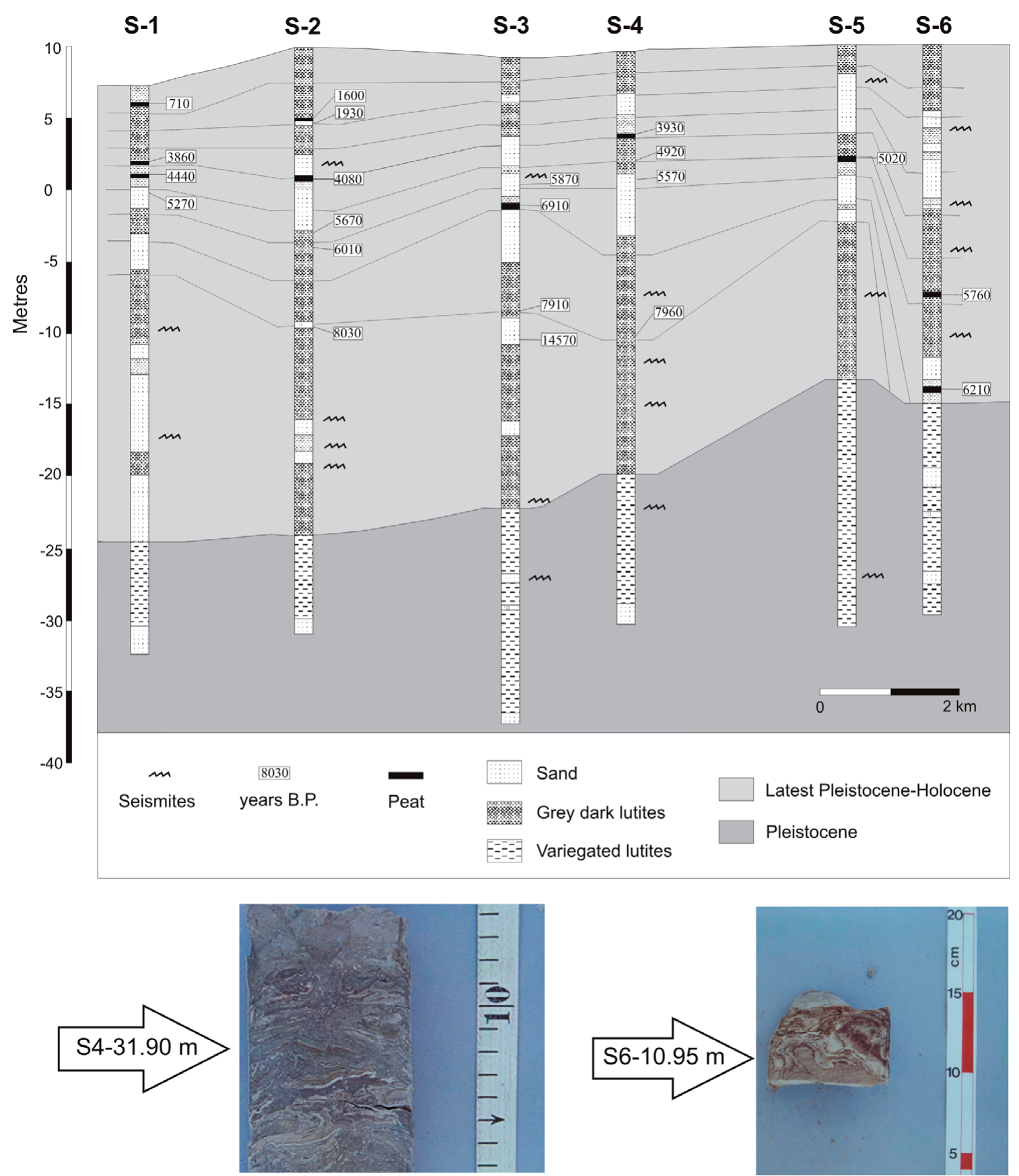

Fig. 8.- A) Simplified NW-SE geological cross-section of the Holocene-latest Pleistocene fill in the Bajo Segura Basin taken from the six boreholes in Soria et al. (1999) and Alfaro et al. (2001). Seismites and ${ }^{14} \mathrm{C}$ dates are represented. B) Two examples of soft-sediment deformation structures interpreted as seismites.

Fig. 8.- A) Corte geológico esquemático NO-SE del relleno de edad Holoceno-Pleistoceno Superior de la cuenca del Bajo Segura, a partir de las columnas de los seis sondeos estudiados (Soria et al., 1999; Alfaro et al., 2001). Se han representados los niveles de sismitas y las dataciones radiométricas de $\mathrm{C}^{14}$. B) Dos ejemplos de estructuras sedimentarias de deformación interpretadas como sismitas.

to the north at $90^{\circ}, 50^{\circ}$ and $20^{\circ}$, respectively (Alfaro et al., 2002a). The western part of the fault zone is composed of the Hurchillo and Torremendo anticlines, which have very different wavelengths. The central part is formed by the Benejúzar and Lomas de la Juliana anticlines, which have similar wavelengths, and a wide syncline to the south that corresponds to the Salinas de Torrevieja. Fi- nally, the eastern part of the fault zone is made up of the Guardamar anticline and the wide Salinas de la Mata syncline. These three parts of the BSFZ are bounded by the NW-SE trending San Miguel de Salinas, Torrevieja and Guardamar faults, which have been interpreted as transfer faults associated with the Bajo Segura thrust (Alfaro et al., 2002a). 


\begin{tabular}{|l|c|c|c|c|c|c|}
\hline Segment name & $\begin{array}{c}\text { Length } \\
(\mathbf{k m})\end{array}$ & $\begin{array}{c}\text { Min. depth } \\
\mathbf{( k m )}\end{array}$ & $\begin{array}{c}\text { Max. depth } \\
(\mathbf{k m})\end{array}$ & $\begin{array}{c}\text { Fault-dip } \\
(\mathbf{(})\end{array}$ & $\begin{array}{c}\text { Area } \\
\left(\mathbf{k m}^{\mathbf{2}}\right)\end{array}$ & Mw \\
\hline Hurchillo & 10 & 1 & 12 & $60-30$ & $127-220$ & $6.6-6.8$ \\
\hline Benejúzar & 9 & 1 & 12 & $60-30$ & $102-176$ & $6.6-6.7$ \\
\hline Guardamar & 8 & 1 & 12 & $60-30$ & $114-198$ & $6.6-6.8$ \\
\hline Bajo Segura Fault (complete) & 27 & 1 & 12 & $60-30$ & $343-594$ & $6.9-7.1$ \\
\hline
\end{tabular}

Table 1. Parameters considered for the estimation of the maximum rupture area and moment magnitude (Mw). See text for details.

Tabla 1. Parámetros utilizados en el cálculo del área máxima de ruptura y la magnitud momento (Mw). Ver detalles en el texto.

\begin{tabular}{|c|c|c|c|c|c|c|c|}
\hline Segment name & $\begin{array}{c}\text { Accumulated } \\
\text { uplift (m) }\end{array}$ & $\begin{array}{c}\text { Age of } \\
\text { marker (ka) }\end{array}$ & $\begin{array}{c}\text { Vertical SR } \\
(\mathbf{m} / \mathbf{k a})\end{array}$ & $\begin{array}{l}\text { Fault- } \\
\operatorname{dip}\left({ }^{\circ}\right)\end{array}$ & $\begin{array}{c}\text { Net SR } \\
(\mathbf{m} / \mathbf{k a})\end{array}$ & $\begin{array}{c}\text { Net SR } \\
\text { Average }\end{array}$ & $\begin{array}{l}\text { Average } \\
\text { deviation }\end{array}$ \\
\hline \multirow{2}{*}{ Hurchillo } & \multirow{2}{*}{606} & 2,000 & 0.30 & \multirow{2}{*}{$60-30$} & $0.35-0.61$ & \multirow{2}{*}{0.40} & \multirow{2}{*}{ \pm 0.11} \\
\hline & & 3,000 & 0.20 & & $0.23-0.40$ & & \\
\hline \multirow{2}{*}{ Benejúzar } & \multirow{2}{*}{406} & 2,000 & 0.20 & \multirow{2}{*}{$60-30$} & $0.23-0.41$ & \multirow{2}{*}{0.27} & \multirow{2}{*}{ \pm 0.07} \\
\hline & & 3,000 & 0.14 & & $0.16-0.27$ & & \\
\hline \multirow{2}{*}{ Guardamar } & \multirow{2}{*}{306} & 2,000 & 0.15 & \multirow{2}{*}{$60-30$} & $0.18-0.31$ & \multirow{2}{*}{0.20} & \multirow{2}{*}{ \pm 0.05} \\
\hline & & 3,000 & 0.10 & & $0.12-0.20$ & & \\
\hline $\begin{array}{l}\text { Bajo Segura Fault } \\
\text { (complete) }\end{array}$ & & & & & & 0.29 & \pm 0.07 \\
\hline
\end{tabular}

Table 2. Estimated slip rates for the Bajo Segura Fault. See text for details.

Tabla 2. Tasas de desplazamiento estimadas para la Falla del Bajo Segura. Ver detalles en el texto.

The dimensions of the maximum rupture area of the Bajo Segura Fault, together or in segments, can be estimated from the length of its projection at the surface by means of the detailed map shown in Fig. 2 (Table 1). We assumed that the actual fault plane is located at approximately $1 \mathrm{~km}$ depth. The maximum depth of the rupture area is estimated at $12 \mathrm{~km}$, at the base of the seismogenic layer, which is interpreted from the rheological profile of the crust and the vertical distribution of seismicity (García Mayordomo, 2005). Finally, the calculation of the rupture area was performed for two dip values $\left(60^{\circ}\right.$ and $\left.30^{\circ}\right)$.

Moment magnitudes (Mw) were calculated from the rupture area by means of the empirical relationship by Stirling et al. (2002) for censored instrumental data. The Mw for the Bajo Segura Fault ranges between 6.6 and 7.1 (Table 1). We consider that these values represent conservative estimates, with a statistical uncertainty (standard deviation) of 0.26 . However, the uncertainty is greater if we consider the assumptions made for the deep geometry of the fault zone.

\subsubsection{Slip rates and recurrence intervals}

Slip rates for the different segments of the Bajo Segura Fault were estimated using the contour map of the contact between Pliocene units I and II (Montenat, 1977) presented in Taboada et al. (1993). This marker bed, which cor- responds to the base of the Rojales Sandstones formation (Montenat, 1977), belongs to the uppermost part of the Early Pliocene (Soria et al., 1996).

According to Alfaro et al. (2002a), the top of this unit dates the onset of folding at approximately 2-3 Ma. Hence, the contour map of Taboada et al. (1993) can be used to account for the accumulated vertical slip during the last 2-3 Ma as long as the thickness of the Rojales formation $(50 \mathrm{~m})$ is also considered in the measurements.

Table 2 summarises the elevation data for each of the folds considering the height difference between the uppermost part of the anticlines, the $50 \mathrm{~m}$ thickness of the Rojales formation and a depth of $-156 \mathrm{~m}$ for the top of the Rojales formation in the Bajo Segura basin (Giménez et al., 2009). Slip rates are then calculated considering ages ranging between 2 and $3 \mathrm{Ma}$ and assuming that the fault dip varies between $60^{\circ}$ and $30^{\circ}$. Dip exerts a stronger control on slip rate than age (Table 2).

The recurrence time (RT) of such an earthquake that ruptures the maximum fault area can be calculated by means of $R T=M_{o} e / M_{o} g$ (Wesnousky, 1986), where $M_{o} e$ is the seismic moment released in such an earthquake, and $M g$ is the seismic moment rate, which depends on the slip rate of the fault. The use of this equation assumes that the fault releases most of the seismic moment in one maximum event. Hence, it provides a practical approx- 


\begin{tabular}{|c|c|c|c|c|}
\hline Segment name & $\begin{array}{c}\text { Average } \\
\text { SR (m/ka) }\end{array}$ & $\begin{array}{l}\text { Recurrence } \\
\text { (yr) }\end{array}$ & $\begin{array}{c}\text { Extreme SR } \\
(\mathbf{m} / \mathbf{k a})\end{array}$ & $\begin{array}{c}\text { Recurrence } \\
\text { (yr) }\end{array}$ \\
\hline Hurchillo & 0.40 & $\begin{array}{c}6,420-6,764 \\
(\mathbf{6 , 6 0 0 )}\end{array}$ & $0.23-0.61$ & $10,963-4,446$ \\
\hline Benejúzar & 0.27 & $\begin{array}{c}9,392-9,885 \\
(\mathbf{9 , 6 0 0 )}\end{array}$ & $0.16-0.41$ & $16,020-6,496$ \\
\hline Guardamar & 0.20 & $\begin{array}{c}12,588-13,262 \\
(\mathbf{1 2 , 9 0 0 )}\end{array}$ & $0.12-0.31$ & $21,495-8,716$ \\
\hline $\begin{array}{l}\text { Bajo Segura Fault } \\
\text { (complete) }\end{array}$ & 0.29 & $\begin{array}{l}9,732-10,254 \\
\quad(\mathbf{1 0 , 0 0 0 )}\end{array}$ & $0.20-0.40$ & $13,973-7,434$ \\
\hline
\end{tabular}

Table 3. Estimated recurrence intervals of maximum earthquakes for the Bajo Segura Fault. Recurrence intervals are calculated using two different rupture areas and for average and extreme values of net slip rate. The preferred estimate is shown in brackets.

Tabla 3. Intervalos de recurrencia de terremotos máximos calculados para la Falla del Bajo Segura. Para el cálculo se han tenido en cuenta dos superficies de ruptura diferentes, así como los valores extremos y el valor medio de la tasa de desplazamiento. Entre paréntesis se indica la estimación más probable.

imation to assess the recurrence time of the maximum earthquake on a fault.

The estimated and preferred recurrence times of maximum earthquakes are summarised in Table 3. Differences based on variations in the rupture area resulting from the different fault dip values do not appear to have a significant impact, whereas the most important variable is slip rate. The extreme recurrence estimates arise from considering the extreme net slip rate values. The preferred estimate is the average of the recurrence values from both possible ruptures areas and the average slip rate. The preferred values are consistent with the estimate from Villamor and Berryman's (1999) regression of recurrence on slip rate (e.g., García-Mayordomo, 2007), and with the average coseismic displacement from the Stirling et al. (2002) equation for censored instrumental data divided by slip rate. Finally, it is worth mentioning that the preferred recurrence times of maximum earthquakes are slightly larger than the upper limit previously proposed in García-Mayordomo and Martínez-Díaz (2006).

\section{Conclusions}

Active tectonic and palaeoseismic studies on blind faults are complex, especially in areas with low to moderate seismic activity such as the BSFZ. Therefore, vertical displacements of geological and geomorphological markers are the only data that can be used to estimate long-term slip rates.

In this study, we used two markers of different ages to estimate uplift rates: the Triassic basement and the Pliocene Rojales Sandstone Formation. In addition, previous research has used Thyrrenian marine terraces (Somoza, 1993) and the Pliocene-Pleistocene (?) Conglomerados del Segura Formation (Taboada et al., 1993). Most of these geological markers indicate uplift rates ranging between 0.1 and $0.3 \mathrm{~mm} /$ year. The higher fault slip rates proposed by Taboada et al. (1993) are due to an age discrepancy of the Plio-Pleistocene marker used in their study. In addition, preliminary geodetic studies (Giménez et al., 2009) indicate an uplift rate of $0.2 \mathrm{~mm} /$ yr for the Bajo Segura Fault, which agrees well with the geological data.

The different fault slip rates have been calculated assuming different ages of the geological markers and different dips of the fault. These estimated fault slip rates and the subsequent recurrence intervals of maximum earthquakes must be considered with caution. Additional geological, geophysical and seismological research is needed to determine the deep geometry of the BSFZ. In any case, the results obtained from the two geological markers and previous research, as well as the preliminary geodetic studies, are consistent with other estimated fault slip rates in the Betic Cordillera.

The maximum moment magnitudes range between 6.6 and 6.8 for individual fault segments and between 6.9 and 7.1 for a complete rupture of the Bajo Segura Fault. These values are also consistent with the estimated magnitude of the 1829 Torrevieja earthquake, which has been estimated as between $\mathrm{Ms}=6.3$ (Delgado et al., 1993) and Ms=6.9 (Muñoz and Udías, 1991).

There is a discrepancy between the estimated recurrence times of maximum earthquakes for the Bajo Segura Fault, between 4500 and 21500 years, and the minimum recurrence of approximately 1000 years proposed by A1faro et al. (2001). The shorter recurrence period obtained by Alfaro et al. (2001) is based on liquefaction features, which can be triggered by earthquakes with lower magnitudes of 5.0 or 5.5. For example, the 1919 composed Jacarilla earthquake, with $\mathrm{mb}=5.1$ and 5.2 , caused liquefaction near Jacarilla. In addition, other seismogenic faults in the area could be for some of these seismites.

Finally, future studies will also need to consider the offshore segments of the BSFZ. Active deformation extends $80 \mathrm{~km}$ offshore, and further examination of recently acquired marine data, including complete bathymetric coverage, may reveal precise maximum magnitudes and recurrence intervals of the earthquakes. 


\section{Acknowledgements}

Financial support for this work was provided by the research projects CGL2011-30153-C02-02, FASEGEO (CGL2009-09726), EVENT (CGL 2006-12861-C02-02) and SHAKE (CGL 2011-30005-C02-02) and Acciones Complementarias EVENT-SHELF (CTM 2008-03346E/MAR) and SPARKER (CTM 2008-03208-E/MAR). We thank the captain, crew, scientific and technical staff on board the Spanish RV "García del Cid" during the EVENT-SHELF cruise. Rafael Bartolomé is a "Ramón y Cajal" researcher and Héctor Perea is a "Juan de la Cierva" researcher funded by the Spanish Ministerio de Economía y Competitividad. We are grateful to Dr. Klaus Reicherter and an anonymous reviewer for their help.

\section{References}

Alfaro, P. (1995): Neotectónica de la Cuenca del Bajo Segura (Cordillera Bética oriental). PhD Thesis, Universidad de Alicante: 211 p.

Alfaro, P., Estévez, A., Moretti, M. y Soria, J.M. (1999): Structures sédimentaries de déformation interprétées comme séismites dans le Quaternaire du bassin du Bas Segura (Cordillère bétique orientale). Comptes Rendues de l'Académie des Sciences de Paris 328, 17-22.

Alfaro, P., Borque, M.J., Estévez, A., Gil, A.J., Molina, S. (2000): Red de control GPS de la Cuenca del Bajo Segura (Cordillera Bética oriental). Geotemas 14, 245-248.

Alfaro, P., Delgado, J., Estévez, A., López-Casado, C. (2001): Paleoliquefaction in the Bajo Segura basin (eastern Betic Cordillera). Acta Geol. Hisp. 36 (3-4), 233-244.

Alfaro, P., Andreu, J.M., Delgado, J., Estévez, A. Soria, J.M., Teixidó, T. (2002a): Quaternary deformation of the Bajo Segura blind fault (eastern Betic Cordillera) revealed by high-resolution reflection profiling. Geological Magazine 139, 3, 331-341. doi:10.1017/ S0016756802006568.

Alfaro, P., Delgado, J., Estévez, A. Soria, J.M., Yébenes, A. (2002b): Onshore and offshore compressional tectonics in the eastern Betic Cordillera (SE Spain). Marine Geology 186, 337-349. doi:10.1016/ S0025-3227(02)00336-5.

Argus, D.F., Gordon, R.G., DeMets, C., Stein, S. (1989): Closure of the Africa-Eurasia-North America Plate Motion Circuit and Tectonics of the Gloria Fault. Journal of Geophysical Research 94, B5, 5585-5602. doi:10.1029/JB094iB05p05585.

Bisbal Cervello, L. (1984): Estudio de la distribución de intensidades sísmicas en el ámbito valenciano. Su incidencia en las obras públicas. PhD. Thesis. Universidad Politécnica de Valencia.

Bousquet, J.C. (1979): Quaternary strike-slip faults in Southeastern Spain. Tectonophysics 52, 277-286. doi:10.1016/00401951(79)90232-4.

Buforn, E., Sanz de Galdeano, C., Udías, A. (1995): Seismotectonics of the Ibero-Maghrebian región. Tectonophysics 248, 247-261. doi:10.1016/0040-1951(94)00276-F.

Coca, P., Buforn, E. (1994): Mecanismos focales en el Sur de España: Periodo 1965-1985. Estudios Geológicos 50, 33-45. doi:10.3989/ egeol.94501-2306.

Comisión Permanente de Normas Sismorresistentes (2002): Norma de construcción sismorresistente: parte general y edificación (NCSR02). Boletín Oficial del Estado, 11 de octubre, n 244, 35898-35967. Delgado, J., López Casado, C. (1999): El terremoto de 1829. In: G.
Canales (ed.), La catástrofe sísmica de 1829 y sus repercusiones. Excma. Dip. Provincial de Alicante, Excmo. Ayto. Almoradí y Universidad de Alicante.

Delgado, J, Giner, J., López-Casado, C., Auernheimer C. (1993): Análisis de la respuesta del suelo en intensidades. Aplicación al terremoto de Torrevieja. In: R. Ortiz (ed.). Problemática Geoambiental y Desarrollo, Murcia. Tomo II, 627-636.

Delgado, J., Alfaro, P., Andreu, J.M., Cuenca, A., Doménech, C., Estévez, A., Soria, J.M., Tomás, R., Yébenes, A. (2003): Engineeringgeological model of the Segura river flood plain (SE Spain): a case study for engineering planning. Engineering Geology 68, 171-187. doi:10.1016/S0013-7952(97)00073-2.

Delgado, J., López-Casado, C., Alfaro, P., Giner, J.J., Estévez, A. (1998): Liquefaction potential in the Lower Segura basin (Southeast Spain). Engineering Geology 49, 61-79.

DeMets, C., Gordon, R.G., Argus, D.F., Stein, S. (1994): Effect of recent revisions to the geomagnetic reversal time scale on estimates of current plate motions. Geophys. Res. Lett. 21, 2191-2194. doi:10.1029/94GL02118.

García-Mayordomo, J. (2005): Caracterización y Análisis de la Peligrosidad Sísmica en el Sureste de España. PhD Thesis, Universidad Complutense de Madrid: 373 pp.

García-Mayordomo, J. (2007): Incorporación de datos y criterios geológicos en el análisis de la peligrosidad sísmica en regiones de actividad moderada: I. Definición y caracterización de fuentes sismogenéticas. Geogaceta 41, 87-90.

García-Mayordomo, J., Martínez-Díaz, J.J. (2006): Caracterización sísmica del anticlinorio del Bajo Segura (Alicante): Fallas del Bajo Segura, Torrevieja y San Miguel de Salinas. Geogaceta 40, 19-22.

Gauyau, F. (1977): Étude geophysique dans le Levant espagnol (entre Alicante et Totana): Le probléme du prolongement de l'accident d'Alhama de Murcia. PhD. Thesis, Univ. de Languedoc: 95 p.

Giménez, J., Suriñach, E., Goula, X. (2000): Quantification of vertical movements in the eastern Betics (Spain) by comparing levelling data. Tectonophysics 317, 237-258. doi:10.1016/S00401951(99)00318-2.

Giménez, J., Borque, M.J., Gil, A., Alfaro, P., Estévez, A., Suriñach, E. (2009): Comparison of long-term and short-term uplift rates along an active blind reverse fault zone (Bajo Segura, SE Spain). Studia Geophysica et Geodaetica 53, 81-98. doi:10.1007/s11200009-0005.

Giner, J.J., Molina, S., Jáuregui, P.J. (2003): Sismicidad en la Comunidad Valenciana (C.V.). Física de la Tierra 15, 163-187.

Gràcia, E., Pallàs, R., Soto, J.I., Comas, M., Moreno, X., Masana, E., Santanach, P., Diez, S., García, M., Dañobeitia, J.J. (2006): Active faulting offshore SE Spain (Alboran Sea): Implications for earthquake hazard assessment in the Southern Iberian Margin. Earth Planet. Sci. Lett. 241 (3-4), 734-749. doi:10.1016/j.epsl.2005.11.009.

Kindelán, V., Gorostizaga, J. (1920): Sobre los terremotos ocurridos en las provincias de Alciante y Murcia en 1919. Bol. Inst. Geol. Min. España 41, 249-261.

Larramendi, J.A. (1829): Memoria y relación circunstanciada de los estragos que la terrible catástrofe de los terremotos de 21 de marzo y siguientes, principalmente, el del sábado 18 de abril hasta el presente día, han causado en Torrevieja y demás pueblos de la Gobernación de Orihuela y sus inmediaciones, en la ciudad de Murcia, y algunos pueblos de la provincia de este nombre. Madrid, Imprenta Real: 24 p.

Masana, E., Martínez-Díaz, J.J., Hernández-Enrile, J.L., Santanach, P. (2004): Constraining seismotectonics in a diffuse collisional plate boundary by paleoseismic results. A preliminary approach along the Alhama de Murcia Fault (Betic Cordillera). J. Geophys. Res. 109, B01301, doi:10.1029/2002JB002359. 
Montenat, C. (1977): Les bassins néogènes et quaternaires du Levant d'Alicante à Murcie (Cordillères bétiques orientales, Espagne). Stratigraphie, paléontologie et evolution dynamique. Docum. Lab. Géol. Fac. Sci. Lyon, 69: 345 p.

Montenat, C., Ott d'Estevou, P., Coppier, G. (1990): Les basins néogènes entre Alicante et Cartagena (Espagne). Doc. et Trav. I.G.A.L. 12-13, 313-368.

Muñoz, D., Udías, A., Moreno, E. (1984): Reevaluación de los datos del terremoto de 1829 (Torrevieja). In: Asociación Española de Ingeniería Sísmica (ed.), Sismicidad Histórica de la Península Ibérica, Madrid: 38-41.

Muñoz, D., Udías, A. (1991): Three large historical earthquakes in Southern Spain. In: J. Mézcua and A. Udías (eds.), Seismicity, Seismotectonics and Seismic Risk of the Ibero-Maghrebian Region. Publ. Inst. Geogr. Nac., 8, Madrid: 175-182.

Perea, H., Gràcia, E., Bartolomé, R., Lo Iacono, C., Masana, E. (2010): Structure and potential seismogenic sources of the offshore Bajo Segura Fault Zone, SE iberian Peninsula (Mediterranean sea). Looking for the source of the 1829 Torrevieja earthquake. In: J.M. Insua and F. Martín-González (eds.), Contribución de la geología al análisis de la peligrosidad sísmica. Guadalajara: 113-116.

Perea, H., Gràcia, E., Alfaro, P., Bartolomé, R., Lo Iacono, C., Moreno, X., Masana, E. and EVENT-SHELF Team (2012): Structure and potential seismogenic sources of the offshore Bajo Segura basin (SE Iberian Peninsula, Mediterranean Sea). Natural Hazards and Earth System Sciences.

Ramírez, M.S., Lucini, M., Herraiz, M. (1998): Análisis del estado de esfuerzos tectónicos, reciente y actual en la Península Ibérica. Proyecto SIGMA. Consejo de Seguridad Nuclear Colección Otros Documentos 10: 239 p.

Rodríguez de la Torre, F. (1984): Los terremotos alicantinos de 1829. Instituto de Estudios Alicantinos. Excma. Diputación Provincial de Alicante. Alicante. Serie I, $\mathrm{n}^{\mathrm{o}}$ 100: 323 p.

Sanz de Galdeano, C., Alfaro, P. (2004): Tectonic significance of the present relief of the Betic Cordillera. Geomorphology 63, 175-190.
Silva, P. (1994): Evolución geodinámica de la depresión del Guadalentín desde el Mioceno superior hasta la actualidad: Neotectónica y Geomorfología. Ph.D. Thesis, UCM, Madrid: 642 p.

Silva, P.G., Goy, J.L., Somoza, L., Zazo, C., Bardají, T. (1993): Landscape response to strike-slip faulting linked to collisional settings: Quaternary tectonics and basin formation in the Eastern Betics, Southeast Spain. Tectonophysics 224, 289-303. doi:10.1016/00401951(93)90034-H.

Somoza, L. (1993): Estudio del Cuaternario litoral entre Cabo de Palos y Guardamar (Murcia-Alicante). Las variaciones del nivel del mar en relación con el contexto geodinámico. Instituto Español de Oceanografía 12: $237 \mathrm{p}$.

Soria, J.M., Alfaro, P., Ruiz Bustos, A., Serrano, F. (1996): Organización estratigráfica y biostratigrafía del Plioceno en el borde sur de la Cuenca del Bajo Segura (sector de Rojales, Alicante), Cordillera Bética Oriental. Estudios Geológicos 52, 137-145. doi:10.3989/ egeol.96523-4261.

Soria, J.M., Alfaro, P., Estévez, A., Delgado, J., Durán, J.J. (1999): The Holocene sedimentation rates in the Lower Segura Basin (eastern Betic Cordillera, Spain) : eustatic implications. Bulletin de la Société Géologique de la France 170, 349-354.

Stirling, M., Rhoades, D. y Berryman, K. (2002): Comparison of earthquake scaling relations derived from data of the instrumental and preinstrumental era. Bulletin of the Seismological Society of America 92(2), 812-830. doi:10.1785/0120000221.

Taboada, A., Bousquet, J.C., Philip, H. (1993): Co-seismic elastic models of folds above blind thrusts in the Betic Cordilleras (Spain) and evaluation of seismic hazard. Tectonophysics 220, 223-241. doi:10.1016/0040-1951(93)90233-A.

Villamor, P., Berryman, K. (1999): La tasa de deslizamiento de una falla como aproximación de primer orden en las estimaciones de peligrosidad sísmica. $1^{e r}$ Congreso Nacional de Ingeniería Sísmica, Murcia, I: 153-163.

Wesnousky, S.G. (1986): Earthquakes, Quaternary faults, and seismic hazard in California. Journal of Geophysical Research 91 (B12), 12587-12631. doi:10.1029/JB091iB12p12587. 